The Technical Fix 


\section{The Technical Fix}

Education, Computers and Industry

Kevin Robins and Frank Webster

Macmillan Education 
ISBN 978-0-333-42901-3 ISBN 978-1-349-20120-4 (eBook)

DOI 10.1007/978-1-349-20120-4

(C) Kevin Robins and Frank Webster 1989

Softcover reprint of the hardcover 1st edition 1989

All rights reserved. For information, write:

Scholarly and Reference Division,

St. Martin's Press, Inc., 175 Fifth Avenue, New York, NY 10010

First published in the United States of America in 1989

ISBN 978-0-312-03111-4

Library of Congress Cataloging-in-Publication Data

Robins, Kevin.

The technical fix: education, computers, and industry / Kevin Robins and Frank Webster.

p. $\mathrm{cm}$.

Bibliography: $p$.

Includes index.

ISBN 978-0-312-03111-4

1. Educational technology. 2. Education-Data processing.

3. Education-Economic aspects. I. Webster, Frank. II. Title. LB1028.3.R59 1989

$370^{\prime} .28-\mathrm{dc} 19$

89-4189

CIP 
For Danny and Joe, Frankie and Isabelle 
'I turn my eyes to the Schools and Universities of Europe And there behold the Loom of Locke, whose woof rages dire,

Wash'd by the Water-wheels of Newton: black the cloth In heavy wreathes folds over every Nation: cruel Works Of many Wheels I view, wheel without wheel, with cogs tyrannic

Moving by compulsion each other, not as those in Eden, which,

Wheel within Wheel, in freedom revolve in harmony \& peace.'

William Blake, Jerusalem (1804-20) 


\section{Contents}

List of Tables

viii

Acknowledgements ix

Introduction 1

PART I THE MYTH OF THE MACHINE

1 Technological Futures and the Technical Fix 11

2 The Origins of the Information Society 33

3 Recession and Restructuring 69

PART II THE INDUSTRIALISATION OF EDUCATION

4 Education, Utopia and Crisis 103

5 The English Disease? 141

6 Education for what Jobs? 170

7 The New Disciplines 201

PART III BEYOND TECHNOCRACY?

8 The Military Project 233

9 The Technocratic Condition, or Schools Cannot Teach what Society does not Know 256

Bibliography 277

$\begin{array}{ll}\text { Index } & 307\end{array}$ 


\section{List of Tables}

4.1 Post-war expansionary regime, late 1940 s to early 1970s 113

4.2 The emergent regime of flexible accumulation, mid-1970s onwards 


\section{Acknowledgements}

An important initial stimulus for the development of this work came from Les Levidow, and I would like to thank him for his continuing support. The background to this book has been very much shaped by the project of Radical Science Journal and its successor Science as Culture, and it is the ideas developed by Les Levidow and Bob Young in these journals that have given me an intellectual framework for many years now. Science as Culture, along with other publications from Free Association Books, is recommended as a journal to follow up many of the issues developed in this book.

Newcastle

KEVIN RoBINS

Writing a book of this sort is unavoidably an isolating affair. At a time of acute economic anxiety, when education is called upon to do its duty by helping industry escape recession by training the young in appropriately technical (and other) skills, undermining 'computer literacy' initiatives is not likely to make one popular. We did not expect approval and anticipated the Luddite labels. In such circumstances it is important to have colleagues, near and far, who may deflect criticism, absorb pressure, and from whom one may draw strength.

I am fortunate to work at an institution that is both supportive and academically stimulating. From the commencement of this book early in 1986, I have had nothing but encouragement, even if sometimes quizzical, from col- 


\section{x Acknowledgements}

leagues at Oxford Polytechnic. Harry Hendrick deserves a special mention since it was at his invitation that I fired a first salvo at 'computer literacy' programmes during a History Society seminar in February 1985. The responses to that paper encouraged me to develop the arguments. In particular I must mention the assistance of Keith Lambe, Martin Joseph, John Astley, Tony Harding, Rob Pope, Peter Madgwick, Alan Jenkins, David Pepper and David Watson. Several of these friends were present at Harry's seminar, and their interest in the 'anti-I.T.' book has helped mine.

Thanks too to the members of the Sociology Subject Committee at the polytechnic, particularly the regular attenders of the Thursday Evening Seminar at the 'Black Boy'. They have been important in bolstering my belief in the validity of education which is more than instrumental.

Many of the themes were rehearsed on students from the Computing and Sociology Fields who enrolled on my courses 'The Information Society?' and 'Issues in Computer Communications Policy'. Their responses helped immeasurably in clarifying my ideas. I thank them.

Acknowledgement too should be made of the Modular Course at Oxford Polytechnic. Its openness to ideas and organisational flexibility allowed me to introduce into several Fields courses which incorporate themes touched on in this book. This refusal of colleagues to reduce education to training has been a source of encouragement to me in my years at Oxford.

Further afield, I have drawn heavily on the community of scholars concerned with information and education. In particular, David and Douglas Noble, Len Masterman, Michael Young and Peter Abbs have been constant stimulants to my thought and writing.

Special mention must be made of Herb and Anita Schiller. They have been intellectual mentors as well as fine friends and hosts to me for several years now. More than anyone else they have asked and tried to answer the central questions of the 'information age'. I salute them and their joint endeavour.

Bill Melody happened to be living in Oxford while much of this book was being written. His keen intellect and 
enthusiastic manner helped it along, as did his friendship on and off the terraces of Oxford United. The Woolgar family gave similar support and diversion.

As ever, I offer special thanks to Liz, Frankie and Isabelle who put up with me writing this book, though I swore the previous one would be the last.

Oxford

Frank Webster 